\title{
PERSISTENCE OF VECTOBAC WDG AND METOPRAG S-2G AGAINST Aedes aegypti LARVAE USING A SEMI-FIELD BIOASSAY IN RIO DE JANEIRO, BRAZIL
}

\author{
José Bento Pereira LIMA(1), Nilson Vieira de MELO(2) \& Denise VALLE(1)
}

\begin{abstract}
SUMMARY
Persistence of Bacillus thuringiensis var. israelensis (Vectobac WDG) and methoprene (Metoprag S-2G) was evaluated against Aedes aegypti late third instar larvae of the Rockefeller strain in a semi-field bioassay. Tests were performed in Rio de Janeiro, using containers made of plastic, iron, concrete and asbestos, placed in a shaded area. The formulations used were $0.2 \mathrm{~g}$ of Vectobac-WDG and 1g of Metoprag S-2G per 100 liters of water in house storage containers. Vectobac WDG was tested twice, in March and in April/May, 2002. In March (temperature ranging from 21.5 to $39.3{ }^{\circ} \mathrm{C}$ ), $70-100 \%$ mortality was observed by the $7^{\text {th }}$ day and declined abruptly thereafter. No significant differences were observed among the container types. In April/May (18.6 to $34.8{ }^{\circ} \mathrm{C}$ ) mortality was higher than $70 \%$ to $30-36$ days in all cases, except in the iron container (40\% mortality on the $12^{\text {th }}$ day). Metoprag S-2G was evaluated in April/May, 2002, and induced mortality higher than $70 \%$ up to 15 days in the plastic and iron containers and only seven days in the concrete container. In the asbestos container, maximal mortality was achieved on day one post-treatment $(66 \%)$. Our results point to a low persistence of both formulations in the weather conditions of Rio de Janeiro.
\end{abstract}

KEYWORDS: Aedes aegypti; Bacillus thuringiensis var. israelensis; Methoprene; Vector control.

\section{INTRODUCTION}

Dengue control is based mainly on the elimination of its vector, the mosquito Aedes aegypti Linnaeus, through the use of chemical insecticides ${ }^{27,28,29}$. In Brazil, since 1967, organophosphates have been used against larvae (temephos) and adults (fenitrothion, malathion) in Ae. aegypti control programs ${ }^{13,16}$. This, however, seems not to be effective, since new epidemic bursts could not be hampered ${ }^{21,22}$. Both the number and the severity of dengue cases are increasing in Brazil. Rio de Janeiro State has the highest number of reported cases in Brazil. In the last epidemic, summer 2001/2002, more than 163,000 cases were reported. There were 1,400 dengue hemorrhagic cases with 53 deaths ${ }^{20}$.

During the year 2000, Ae. aegypti populations from several Rio de Janeiro municipalities were found to be resistant to temephos, the sole larvicide in the Brazilian Dengue Control Program ${ }^{13}$. Two potential alternative insecticides have been recommended by the Brazilian Health Ministry to face this problem, the biolarvicide Bacillus thuringiensis var. israelensis (Bti) and Methoprene, a Juvenile Hormone (JH) analog 8,17 . Although their safety to the environment and their efficacy against a variety of mosquito species have been demonstrated by several authors, both in laboratory and field conditions, their use in mosquito vector control programs is less studied $\mathrm{d}^{4,5,10,26,30}$.
In this study we evaluated the persistence of one Bti formulation (Vectobac WDG) and one Methoprene formulation (Metoprag S-2G) against Ae. aegypti larvae of the Rockefeller strain in mesocosms which incorporated some of the structure and function of Ae. aegypti larval sites.

\section{MATERIALS AND METHODS}

Mosquitoes: Ae. aegypti late third instar larvae $\left(\mathrm{L}_{3}\right)$ of the Rockefeller strain were used in all assays. Mosquitoes were reared at $26 \pm 1{ }^{\circ} \mathrm{C}$ and $80 \%$ relative humidity. In order to induce synchronization of larva emergence, eggs were immersed in dechlorinated water for one hour. Hamster food (Purina, Paulínia, SP) was supplied daily to feed the larvae.

Formulations: Granular formulations of Bti and Methoprene were used. Vectobac WDG (3,000 ITU, Abbott Laboratórios do Brasil Ltda., Illinois, USA) and Metoprag S-2G (2\% AI, Bernardo Química Comércio e Indústria, São Vicente, SP, Brazil lot no. 001) were applied following indications of the PNCD (0.2 g/100 liters) and the manufacturer (1.0 $\mathrm{g} / 100$ liters), respectively.

Outdoor conditions: A total of 12 containers, three of each source (plastic, iron, concrete and asbestos) were randomly placed inside a

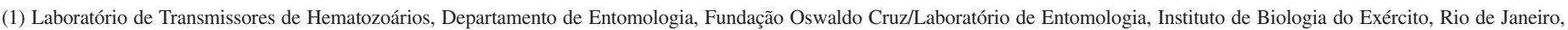
RJ, Brazil.

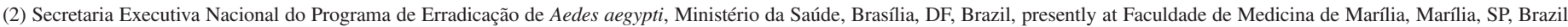

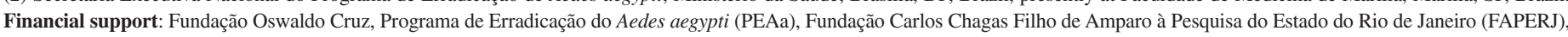
Conselho Nacional de Desenvolvimento Científico e Tecnológico (CNPq) and Fundação Nacional de Saúde (FUNASA).

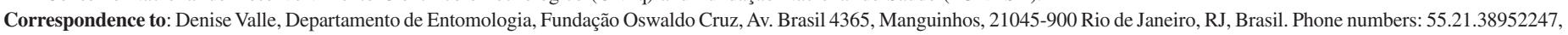
55.21.25806598. E-mail: dvalle@ioc.fiocruz.br 
$12 \mathrm{~m}^{2}$ area in the district of Benfica, Rio de Janeiro. The containers' capacity was 100 liters (concrete), 200 liters (iron, plastic) and 250 liters (asbestos). The area was surrounded with wire netting to avoid access of domestic animals. An inclined plastic cover (Electroplastic, from Agroplas, Santiago, Chile), $3.4 \mathrm{~m}$ high on one side and $2.0 \mathrm{~m}$ high on the opposite side, was installed to protect the area from rain, besides providing partial shading.

Daily temperature data were obtained from the National Meteorology Institute (INMET, 83743 Station, Rio de Janeiro). A digital luximeter (Minipa, model MLM-1332) was used to measure both the sunlight intensity in the partially shaded test area and in the area situated outside it, directly exposed to the sunlight. This was done during one sunny and one cloudy day for each test, at one-hour intervals. In all cases it was verified that $40-60 \%$ of the sunlight crossed the plastic cover.

Bti persistence assays: Two assays were performed, from March 12 to March 28, 2002 (temperature ranging from 21.5 to $39.3{ }^{\circ} \mathrm{C}$ ) and from April 9 to May 25, 2002 (temperature from 18.6 to $34.8^{\circ} \mathrm{C}$ ). In both assays, one container of each source received Vectobac WDG and one container, used as control, was filled with tap water. Persistence tests were performed essentially according to LIMA et al. ${ }^{14}$, using five and three test devices, for experimental and control containers, respectively. The test devices consisted of polyvinylchloride pipes measuring $7.5 \mathrm{~cm}$ in diameter $\mathrm{x} 50 \mathrm{~cm}$ in height. Two stripes of nylon mesh were placed laterally on the pipes to allow permanent contact of the larvae with the water. The devices had the height of the water column inside the majority of the containers, enabling larvae access to different water depths. The test devices floated freely inside the container by means of a Styrofoam plate. Each test device received 20 late $\mathrm{L}_{3}$ larvae and the mortality was recorded 24 and 48 hours later. All larvae from each previous test were discarded before starting a new test. No food was added during the assay period. Water was added only to replace evaporation loss.

Methoprene persistence assay: Metoprag S-2G persistence was evaluated from April 9 to May 19, 2002, in the same area and using the same types of containers mentioned above. Since Methoprene primary effect is the adult emergence inhibition, and not mortality, test specimens were followed through several days, until death or adult emergence. At weekly intervals, fifty late $\mathrm{L}_{3}$ larvae were directly exposed to the experimental and control containers. Daily mortality was recorded, dead specimens were removed and live pupae were transferred to small plastic closed cups, measuring $11 \mathrm{~cm}$ diameter and $11 \mathrm{~cm}$ height. Each cup contained three windows covered with nylon mesh. Two of them, disposed laterally, remained below the water line and the third one, placed on the upper part of the cup, was used to insert pupae and to remove adults. These cups floated freely inside the containers by means of a Styrofoam plate. Dead pupae and adults, and live adults were removed daily from the plastic cups. Weekly, before introducing more test larvae, all specimens remaining inside the containers were transferred to one of the polyvinylchloride test devices described above and small pellets of hamster food were added to feed larvae. All remaining larvae and pupae were followed until mortality or adult emergence.

Analysis of data: Comparisons between 24 and 48 hours data in the Bti tests and among the various types of containers in all the assays were performed with one-way ANOVA/Newman Keuls multiple comparison tests. Comparison of mean temperatures was performed through Mann-Whitney test. Student's t-test was used to evaluate differences between experimental and control containers, in each case ${ }^{24}$.

\section{RESULTS}

Persistence of Vectobac WDG: Differences in Vectobac WDG persistence were found between the tests performed in March and in April/May, 2002. In the first test, when results were evaluated after 24 hours exposure, larva mortality dropped from $70-100 \%$ on the $9^{\text {th }}$ day to $0-7 \%$ on the $15^{\text {th }}$ day (Fig. 1A). In this test, no significant differences were found among the container types $(\mathrm{p}>0.05)$. Comparison of mortality data obtained after 48 hours exposure did not change the results (Table 1).

In contrast, in the test performed in April/May, 2002, evaluation after 24 hours of exposure showed that residual activity (mortality rate higher than 70\%) was attained until 30-36 days in all the containers, with exception of the metal container ( $40 \%$ mortality on the $12^{\text {th }}$ day) (Fig. 1B). Statistical analysis confirmed differences in larval mortality between the metal container and the concrete $(\mathrm{p}<0.05)$, asbestos and plastic $(\mathrm{p}<0.01)$ containers. No significant differences were found between evaluations performed after 24 and 48 hours exposure (Table 2).

Local temperature varied greatly between both tests, ranging from 21.5 to $39.3{ }^{\circ} \mathrm{C}$ in March and from 18.6 to $34.8^{\circ} \mathrm{C}$ in April (Fig. 1C, D). Significant differences were found after comparison of maximal, minimal ( $\mathrm{p}<0.001$ in both cases) and mean $(\mathrm{p}<0.05)$ temperatures registered during each test.

Persistence of Metoprag S-2G: Larvae were exposed to Metoprag S-2G in containers of different sources and total mortality was recorded (Fig. 2). Residual activity was attained for 15 days in the plastic and iron containers and for seven days in the concrete container. Maximal

Table 1

Mortality of Ae. aegypti larvae after 24 or 48 hours of exposure to WDG S-2G in a semi-field bioassay performed in Rio de Janeiro in March, 2002

\begin{tabular}{ccccccccc}
\hline Days post-treatment & \multicolumn{2}{c}{ plastic } & \multicolumn{2}{c}{ iron } & \multicolumn{2}{c}{ concrete } \\
& $24 \mathrm{~h}$ & $48 \mathrm{~h}$ & $24 \mathrm{~h}$ & $48 \mathrm{~h}$ & $24 \mathrm{~h}$ & $48 \mathrm{~h}$ & $24 \mathrm{~h}$ \\
\hline $\mathbf{1}$ & $20 \pm 0$ & $20 \pm 0$ & $20 \pm 0$ & $20 \pm 0$ & $20 \pm 0$ & $20 \pm 0$ & $20 \pm 0$ \\
$\mathbf{9}$ & $20 \pm 0$ & $20 \pm 0$ & $20 \pm 0$ & $20 \pm 0$ & $14 \pm 5$ & $16.8 \pm 4.0$ & $14.2 \pm 3.2$ & $17.2 \pm 1.9$ \\
$\mathbf{1 5}$ & $0 \pm 0$ & $0.2 \pm 0.4$ & $0 \pm 0$ & $0.8 \pm 1.8$ & $1.4 \pm 0.9$ & $1.4 \pm 0.9$ & $0 \pm 0$ & $0.2 \pm 0.4$ \\
\hline
\end{tabular}

In all cases, numbers refer to the mean \pm standard deviation. 

trop. S. Paulo, 47(1):7-12, 2005.

mortality in the asbestos container was $66 \%$, on the first day after treatment.

Fig. 3 shows mortality data for each developmental stage in the

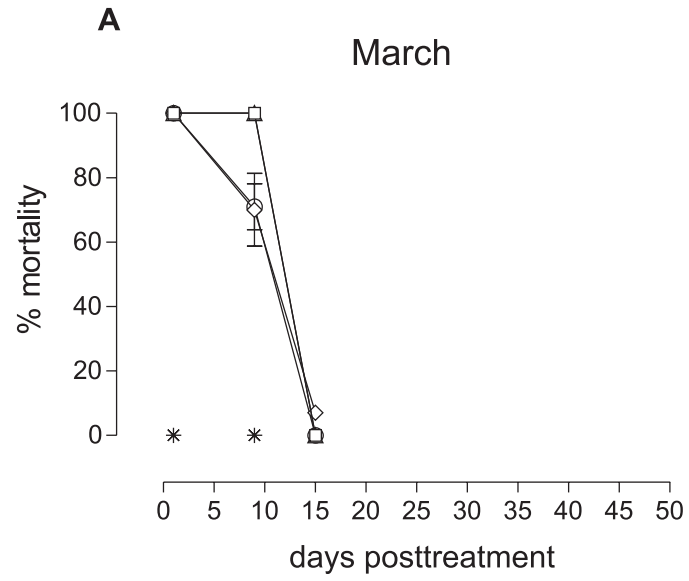

C

March

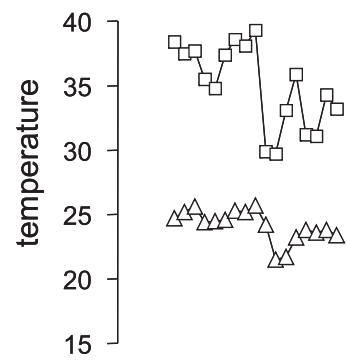

\begin{tabular}{lllllllllll}
\hline 0 & 5 & 10 & 15 & 20 & 25 & 30 & 35 & 40 & 45 & 50
\end{tabular} days posttreatment different containers. Major mortality occurred during the pupal stage mainly at the beginning of the assay. In all cases, 10-25\% larval mortality was noted in the test performed immediately after Metoprag S-2G application. In the plastic and iron containers, larval mortality

B April / May

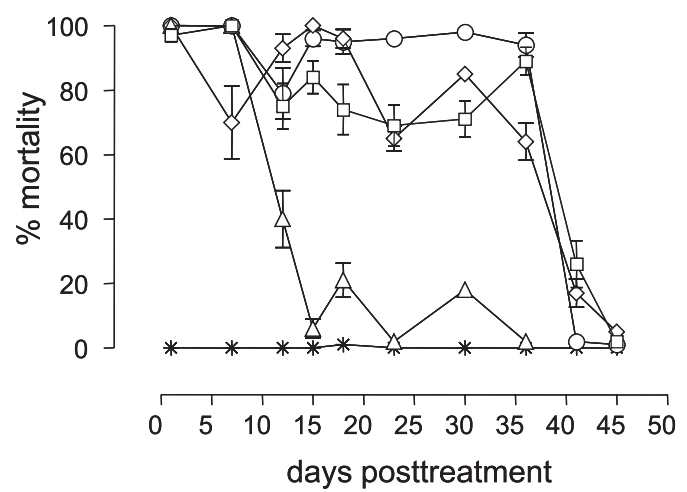

D

April / May

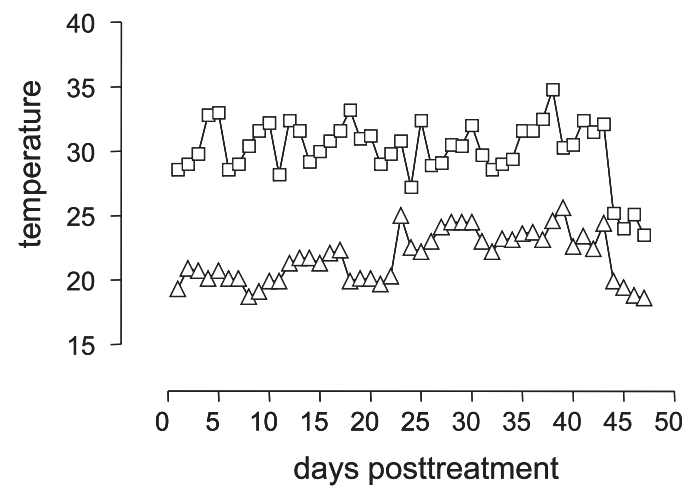

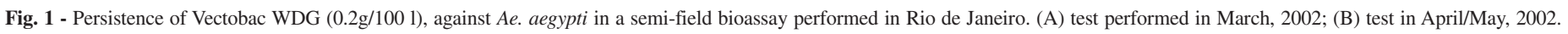

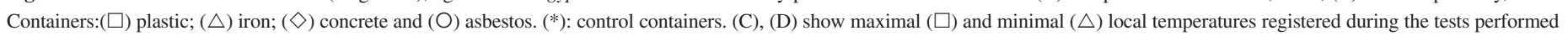
in March and April/May, respectively.

Table 2

Mortality of Ae. aegypti larvae after 24 or 48 hours of exposure to WDG S-2G in a semi-field bioassay performed in Rio de Janeiro in April/May, 2002

\begin{tabular}{|c|c|c|c|c|c|c|c|c|}
\hline \multirow[t]{2}{*}{ Days post-treatment } & \multicolumn{2}{|c|}{ plastic } & \multicolumn{2}{|c|}{ iron } & \multicolumn{2}{|c|}{ concrete } & \multicolumn{2}{|c|}{ asbestos } \\
\hline & $24 \mathrm{~h}$ & $48 \mathrm{~h}$ & $24 \mathrm{~h}$ & $48 \mathrm{~h}$ & $24 \mathrm{~h}$ & $48 \mathrm{~h}$ & $24 \mathrm{~h}$ & $48 \mathrm{~h}$ \\
\hline 1 & $19.4 \pm 0.9$ & $20 \pm 0$ & $20 \pm 0$ & $20 \pm 0$ & $20 \pm 0$ & $20 \pm 0$ & $20 \pm 0$ & $20 \pm 0$ \\
\hline 7 & $20 \pm 0$ & $20 \pm 0$ & $20 \pm 0$ & $20 \pm 0$ & $14 \pm 5$ & $14 \pm 5.0$ & $20 \pm 0$ & $20 \pm 0$ \\
\hline 12 & $15 \pm 3$ & $18.8 \pm 1.6$ & $8 \pm 4$ & $14.8 \pm 1.9$ & $18.6 \pm 2$ & $19.4 \pm 0.5$ & $15.8 \pm 3.5$ & $18.8 \pm 1.6$ \\
\hline 15 & $16.4 \pm 2.4$ & $19 \pm 2.4$ & $1.2 \pm 1.3$ & $6 \pm 1.6$ & $20 \pm 0$ & $20 \pm 0$ & $19.2 \pm 1.0$ & $19 \pm 2.2$ \\
\hline 18 & $14.8 \pm 3.5$ & $16 \pm 2.7$ & $4.2 \pm 2.4$ & $9.2 \pm 0.8$ & $19.2 \pm 1.3$ & $20 \pm 0$ & $19 \pm 1.7$ & $18.2 \pm 2.4$ \\
\hline 23 & $13.8 \pm 2.5$ & $17.4 \pm 2.4$ & $0.4 \pm 0.9$ & $4.2 \pm 1.6$ & $13 \pm 1.7$ & $16.2 \pm 0.4$ & $19.2 \pm 0.8$ & $16 \pm 2.7$ \\
\hline 30 & $14.2 \pm 2.5$ & $20 \pm 0$ & $3.6 \pm 0.5$ & $4.2 \pm 1.3$ & $17 \pm 1$ & $19 \pm 1$ & $19.6 \pm 0.9$ & $17.4 \pm 2.4$ \\
\hline 36 & $17.5 \pm 2.0$ & $10.4 \pm 2.9$ & $0.4 \pm 0.9$ & $3 \pm 1$ & $12.8 \pm 2.6$ & $18.8 \pm 1.3$ & $18.8 \pm 1.6$ & $20 \pm 0$ \\
\hline 41 & $5.2 \pm 3.3$ & $0.4 \pm 0.5$ & & & $3.4 \pm 2$ & $4.4 \pm 3.9$ & $0.4 \pm 0.9$ & $10.4 \pm 2.8$ \\
\hline 45 & $0.4 \pm 0.5$ & & & & $1 \pm 0.7$ & $1.8 \pm 1$ & $0.2 \pm 0.4$ & $0.4 \pm 0.5$ \\
\hline
\end{tabular}

In all cases, numbers refer to the mean \pm standard deviation. 


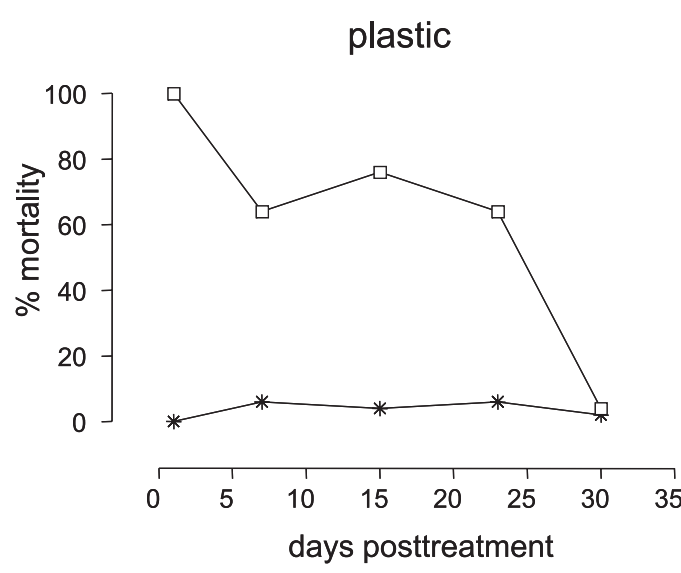

concrete

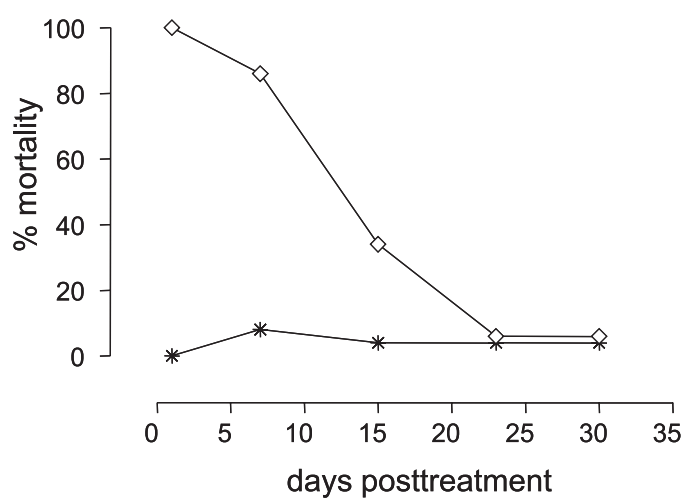

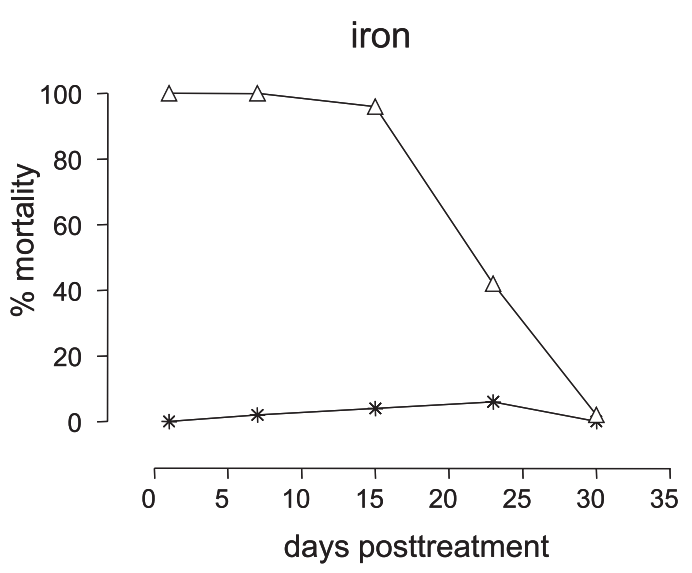

asbestos

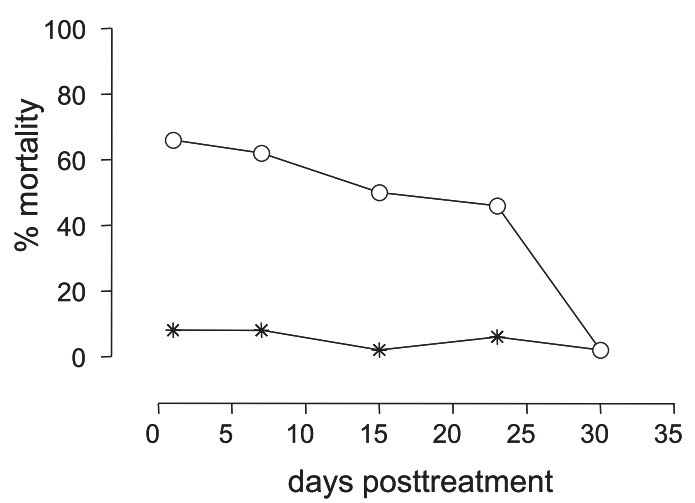

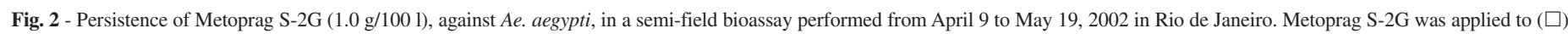
plastic; $(\triangle)$ iron; $(\diamond)$ concrete and $(\bigcirc)$ asbestos containers. $(*)$ : control containers. In each case, data are expressed as the rate of total mortality.

was also observed at other days post-treatment. Adult mortality occurred in the iron and asbestos containers.

\section{DISCUSSION}

$B t i$ - Residual activity of the Bti formulation varied from nine (March, 2002) to 30-36 days (April/May, 2002). This was consistent with previous reports dealing with Bti formulations. SU \& MULLA ${ }^{25}$, working with a WDG Bti formulation in field simulation tests, observed significant control of Culex mosquitoes for 7-12 days. BATTRA et al. ${ }^{3}$ observed $100 \%$ control of Ae. aegypti larvae for a period of two and three weeks in coolers and tires, respectively. The residual activity of other commercial and experimental Bti formulations against mosquitoes generally does not exceed four weeks ${ }^{1,15,23}$.

Temperature is well known to negatively affect the persistence of Bti. Our data showed an inverse relationship between Vectobac WDG persistence and temperature. Accordingly, other authors have verified persistence variation of different Bti formulations as a function of weather conditions ${ }^{14,15}$.

Metoprag S-2G - Metoprag S-2G, used in the dosage recommended by the manufacturer, showed a residual activity of 15 days in the plastic and metal containers and of seven days in the concrete container. In the asbestos container $70 \%$ mortality was never attained. These differences in persistence according to the type of container may reflect distinct affinity of methoprene for each kind of material and should be taken into account in any control program.

Other authors that used standard methoprene concentrations also observed similar persistence ${ }^{6,10,18}$. The increase of the concentration of Methoprene has been shown to elevate mortality. For example, control of Ae. taeniorhynchus could be achieved during three to six weeks with slight increases in Altosid (another methoprene formulation) standard dosage. On the other hand, equivalent Altosid concentrations did not succeed to control Culex quinquefasciatus larvae ${ }^{9,10}$. However, the use of excessive methoprene concentrations led to long-term protection. This was also the case of Ae. albopictus control, attained during 150 days, when 48 times the recommended dosage was employed $^{19}$ and of Culex control during 15 weeks, when 325 times the standard dosage was used ${ }^{12}$.

When Metoprag S-2G effect was recorded for each developmental stage, it was verified that mortality was induced mainly at the pupal 


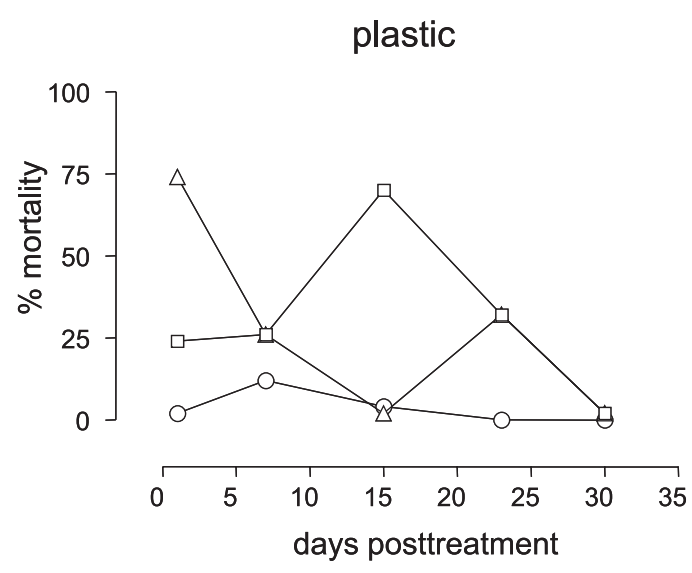

concrete

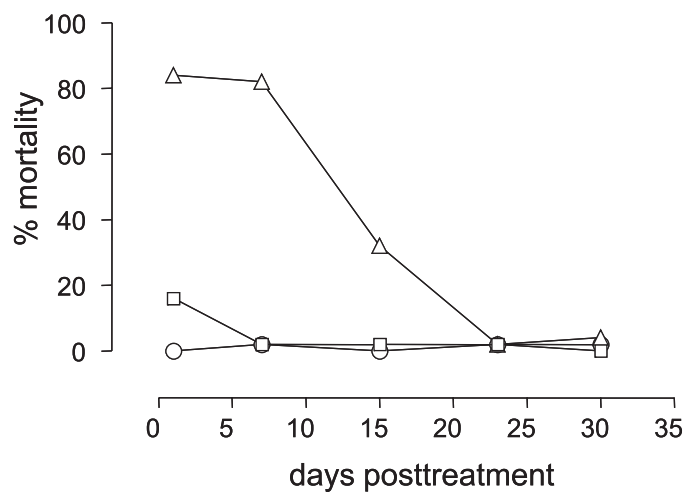

iron

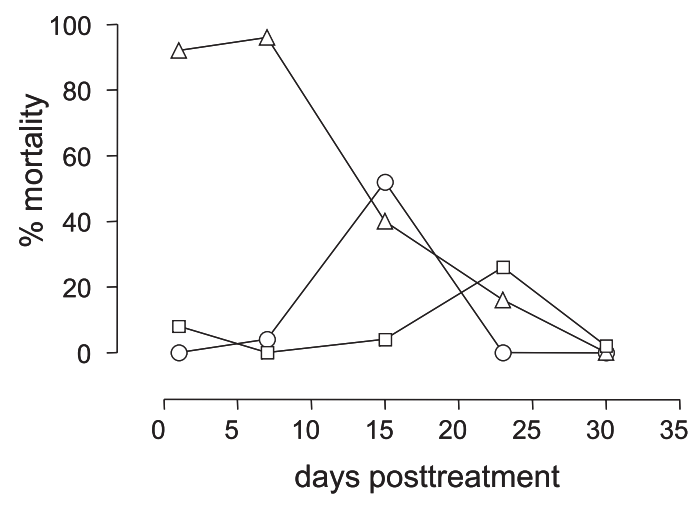

asbestos

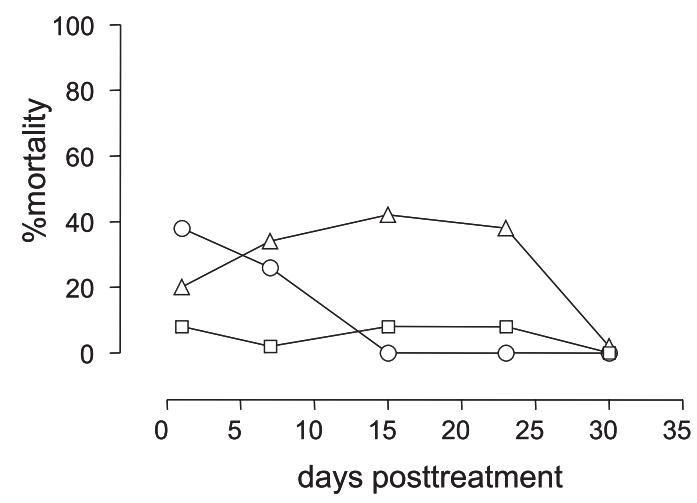

Fig. 3 - Persistence of Metoprag S-2G against Ae. aegypti, expressed as mortality rate per stage. $(\square)$ larvae; $(\triangle)$ pupae and $(O)$ adults.

stage. These data are in agreement with the predicted methoprene mode of action ${ }^{2,17}$, already observed in field tests ${ }^{7}$.

The low persistence of Bti and Metoprag assays described here was obtained without water replacement. An even lower residual effect of these formulations is expected in house storage containers, subjected to water usage and refill with rainfalls. There are several reports showing a reduction of Bti and methoprene persistence when the test area is subjected to rainfalls, when compared to assays performed without water replacement ${ }^{1,11,12,23}$.

Test of different concentrations of these products, as well as of other Bti and methoprene formulations, or even new products, could reveal novel ways of controlling Ae. aegypti in the country. Additionally, test of biolarvicides and IGRs using recently established colonies derived from local populations are planned. These products are envisaged as alternatives of Ae. aegypti control in Brazil, where resistance of populations of the dengue vector to chemical insecticides is increasing in many municipalities.

\section{RESUMO}

\section{Persistência de Vectobac WDG e Metoprag S-2g contra larvas de Aedes aegypti em ensaio simulado de campo no Rio de Janeiro, Brasil}

A persistência de Bacillus thuringiensis var. israelensis (Vectobac WDG) e de Metoprene (Metoprag S-2G) contra larvas de terceiro estadio de Aedes aegypti (linhagem Rockefeller) foi avaliada em ensaios simulados de campo. Os testes foram realizados no Rio de Janeiro, em recipientes domésticos para estoque de água de plástico, ferro, cimento ou amianto, instalados em área sombreada. As formulações foram usadas nas concentrações de 0.2g / 1001 (Vectobac-WDG) e 1g / 100 1 (Metoprag S-2G). Vectobac WDG foi submetido a dois testes, em março e abril/maio, 2002. Em março (temperaturas entre 21.5 e 39.3 $\left.{ }^{\circ} \mathrm{C}\right), 70-100 \%$ de mortalidade foi observada no sétimo dia, declinando posteriormente. Não houve diferença significativa entre os recipientes. Em abril / maio $\left(18.6\right.$ a $\left.34.8^{\circ} \mathrm{C}\right)$ a mortalidade foi superior a $70 \%$ até 30-36 dias em todos os casos, exceto no recipiente de ferro (40\% de mortalidade no $12^{\circ}$ dia). Metoprag S-2G, avaliado em abril / maio, 2002 , induziu mortalidade acima de $70 \%$ durante 15 dias nos recipientes de plástico e de ferro e por apenas sete dias naquele de cimento. No recipiente de amianto, nunca se atingiu $70 \%$ de mortalidade. Estes resultados apontam para uma baixa persistência de ambas formulações nas condições climáticas do Rio de Janeiro.

\section{ACKNOWLEDGEMENTS}

The authors thank Gilberto Couto Alcântara and Henrique Marques da Costa Ramon for technical assistance and the Instituto de Biologia do Exército for laboratory facilities. This work was supported by 
Fundação Oswaldo Cruz, Programa de Erradicação do Aedes aegypti (PEAa), Fundação Carlos Chagas Filho de Amparo à Pesquisa do Estado do Rio de Janeiro (FAPERJ), Conselho Nacional de Desenvolvimento Científico e Tecnológico (CNPq) and Fundação Nacional de Saúde (FUNASA).

\section{REFERENCES}

1. ALI, A.; XUE, R.; LOBINSKE, R. \& CARANDANG, N. - Evaluation of granular corncob formulations of Bacillus thuringiensis serovar israelensis against mosquito larvae using a semi-field bioassay method. J. Amer. Mosq. Control Ass., 10: 492-495, 1994.

2. ARIAS, J.R. \& MULLA, M.S. - Morphogenetic aberrations induced by a juvenile hormone analogue in the mosquito Culex tarsalis (Diptera: Culicidae). J. med. Entomol., 12: 309-316, 1975.

3. BATRA, C.P.; MITTAL, P.K. \& ADAK, T. - Control of Aedes aegypti breeding in desert coolers and tires by use of Bacillus thuringiensis var. israelensis formulation. J. Amer. Mosq. Control Ass., 16: 321-323, 2000.

4. BECKER, N. - Microbial control of mosquitoes: management of the upper Rhine mosquito population as a model programme. Parasit. today, 13: 485-487, 1997.

5. BROWN, M.D.; THOMAS, D.; WATSON, K. \& HAY, B.H. - Laboratory and field evaluation of efficacy of VectoBac ${ }^{\circledR} 12 \mathrm{AS}$ against Culex sitiens (Diptera: Culicidae) larvae. J. Amer. Mosq. Control Ass., 14: 183-185, 1998.

6. CASE, T.J. \& WASHINO, R.K. - Effects of the growth regulator methoprene on Culex tarsalis and non-target organisms in California rice fields. Mosq. News, 38: 191196, 1978.

7. DAME, D.A.; LOWE, R.E.; WICHTERMAN, G.J. et al. - Laboratory and field assessment of insect growth regulators for mosquito control. Mosq. News, 36: 462-472, 1976.

8. FEDERICI, B.A. - The future of microbial insecticides as vector control agents. J. Amer. Mosq. Control Ass., 11: 260-268, 1995.

9. FLOORE, T.G.; RATHBURN Jr., C.B.; BOIKE Jr., A.H.; RODRIGUEZ, H.M. \& COUGHLIN, J.S. - Small plot test of sustained-release Altosid ${ }^{\circledR}$ (methoprene) pellets against Aedes taeniorhynchus in brackish water. J. Amer. Mosq. Control Ass., 6: 133-134, 1990

10. FLOORE, T.G.; RATHBURN Jr., C.B.; DUKES, J.C.; CLEMENTS Jr., B.W. \& BOIKE Jr., A.H. - Control of Aedes taeniorhynchus and Culex quinquefasciatus emergence with sustained release Altosid ${ }^{\circledast}$ sand granules and pellets in saltwater and freshwater test plots. J. Amer. Mosq. Control Ass., 7: 405-408, 1991.

11. KLINE, D.L. - Small plot evaluation of a sustained-release sand granule formulation of methoprene (SAN 810 I 1.3 GR) for control of Aedes taeniorhynchus. J. Amer. Mosq. Control Ass., 9: 155-157, 1993.

12. KNEPPER, R.G.; LECLAIR, A.D.; STRICKLER, J.D. \& WALKER, E.D. - Evaluation of methoprene (Altosid ${ }^{\oplus} \mathrm{XR}$ ) sustained-release briquets for control of Culex mosquitoes in urban catch basins. J. Amer. Mosq. Control Ass., 8: 228-230, 1992.

13. LIMA, J.B.P.; PEREIRA-DA-CUNHA, M.; CARNEIRO-DA-SILVA Jr., R.; et al. Resistance of Aedes aegypti to organophosphates in several municipalities in the state of Rio de Janeiro and Espírito Santo, Brazil. Amer. J. trop. Med. Hyg., 68: 329-333, 2003
14. LIMA, J.B.P.; MELO, N.V. \& VALLE, D. - Residual effect of two Bacillus thuringiensis var. israelensis products assayed against Aedes aegypti (Diptera: Culicidae) in laboratory and outdoors at Rio de Janeiro, Brazil. Rev. Inst. Med. trop. S. Paulo (2005).

15. MELO-SANTOS, M.A.V.; SANCHES, E.G.; JESUS, F.J. \& REGIS, L. - Evaluation of a new tablet formulation based on Bacillus thuringiensis sorovar. israelensis for larvicidal control of Aedes aegypti. Mem. Inst. Oswaldo Cruz, 96: 859-860, 2001.

16. MINISTÉRIO DA SAÚDE - Endemias rurais: métodos de trabalho adotados pelo DNERu. Brasília, Departamento Nacional de Endemias Rurais/Ministério da Saúde, 1968.

17. MULLA, M.S. - The future of insect growth regulators in vector control. J. Amer. Mosq. Control Ass., 11: 269-273, 1995

18. MULLA, M.S. \& DARWAZEH, H.A. - Efficacy of new insect growth regulators against mosquito larvae in dairy wastewater lagoons. J. Amer. Mosq. Control Ass., 4: 322 $325,1988$.

19. NASCI, R.S.; WRIGHT, G.B. \& WILLIS, F.S. - Control of Aedes albopictus larvae using time-release larvicide formulations in Louisiana. J. Amer. Mosq. Control Ass., 10: 1-6, 1994.

20. SILVA Jr., J.B.; SIQUEIRA Jr., J.B.; COELHO, G.E.; VILARINHOS, P.T. \& PIMENTA Jr., F.G. - Dengue in Brazil: current situation and prevention and control activities. Epidem. Bull., 23(1): 3-6, 2002.

21. SCHATZMAYR, H.G. - Dengue situation in Brazil by year 2000. Mem. Inst. Oswaldo Cruz, 95 (suppl. 1): 179-181, 2000

22. SILVEIRA, A.C. - Dengue: aspectos epidemiológicos e de controle. Rev. Soc. bras. Med. trop., 31(suppl 2): 5-14, 1998.

23. SKOVMAND, O. \& SANOGO, E. - Experimental formulations of Bacillus sphaericus and $B$. thuringiensis israelensis against Culex quinquefasciatus and Anopheles gambiae (Diptera: Culicidae) in Burkina Faso. J. med. Entomol., 36: 62-67, 1999.

24. SOKAL, R.R \& ROHLF, F.J. - Biometry: the principles and practice of statistics in biological research. 4. ed. New York, W.H. Freeman, 1994.

25. SU, T. \& MULLA, M.R. - Field evaluation of new water-dispersible granular formulation of Bacillus thuringiensis ssp. israelensis and Bacillus sphaericus against Culex mosquitoes in microcosms. J. Amer. Mosq. Control Ass., 15: 356-365, 1999.

26. SUN, C.N.; GEORGHIOU, G.P. \& WEISS, K. - Toxicity of Bacillus thuringiensis var israelensis to mosquito larvae variously resistant to conventional insecticides. Mosq. News, 40: 614-618, 1980.

27. TUN-LIN, W.; KAY, B.H. \& BARNES, A. - Understanding productivity, a key to Aedes aegypti surveillance. Amer. J. trop. Med. Hyg., 53: 595-601, 1995.

28. WORLD HEALTH ORGANIZATION - Dengue haemorrhagic fever. Diagnosis, treatment, prevention and control. 2. ed. Geneva, WHO, 1997.

29. WORLD HEALTH ORGANIZATION - Dengue prevention and control. Report by the Secretariat. Fifty-fifth World Health Assembly, A55/19. WHO, Geneva, 2002.

30. WOODROW, R.J.; HOWARD, J.J. \& WHITE, D.J. - Field trials with methoprene, temephos, and Bacillus thuringiensis serovar israelensis for the control of larval Culiseta melanura. J. Amer. Mosq. Control Ass., 11: 424-427, 1995.

Received: 30 August 2004

Accepted: 25 November 2004 